\title{
Diagnostic value of serum procalcitonin, lactate, and high- sensitivity C-reactive protein for predicting bacteremia in adult patients in the emergency department
}

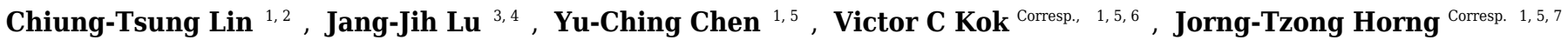 \\ 1 Department of Bioinformatics and Medical Engineering, Asia University Taiwan, Taichung, Taiwan \\ 2 Department of Laboratory Medicine, China Medical University Hospital, Taichung, Taiwan \\ 3 Department of Laboratory Medicine, Chang Gung Memorial Hospital at Linkou, Taoyuan, Taiwan \\ 4 Department of Medical Biotechnology and Laboratory Science, College of Medicine, Chang Gung University, Taoyuan, Taiwan \\ 5 Disease Informatics Research Group, Asia University Taiwan, Taichung, Taiwan \\ 6 Department of Internal Medicine, Kuang Tien General Hospital, Taichung, Taiwan \\ 7 Department of Computer Science and Information Engineering, National Central University, Taoyuan, Taiwan \\ Corresponding Authors: Victor C Kok, Jorng-Tzong Horng \\ Email address: victorkok@asia.edu.tw, horng@db.csie.ncu.edu.tw
}

Background. Few studies compared the diagnostic value of procalcitonin with a combination of other tests including lactate and high-sensitivity C-reactive protein in the prediction of pathogenic bacteremia in emergency department adult patients.

Methods. We performed a retrospective cross-sectional study assessing the differences in performances of procalcitonin, lactate, high-sensitivity C-reactive protein and their combinations for predicting bacteremia in adult patients admitted to the emergency department. Sensitivity, specificity, overall accuracy, positive-test and negative-test likelihood, and diagnostic odds ratio with 95\% confidence interval for each test combination were calculated for comparison. The receiver operating characteristic curve for every single test were compared using DeLong's method. We also performed a sensitivity analysis in two expanded patient cohorts to assess the discriminative ability of procalcitonin or test combination.

Results. A total of 886 patients fulfilled the selection criteria for this study forming the initial patient cohort. For prediction of gram-negative bacteremia, the receiver operating characteristic curves analyses revealed that procalcitonin at a cutoff of $0.5 \mathrm{ng} / \mathrm{mL}$ had the area under the receiver operating characteristic curve of 0.79 (95\% confidence interval, $0.76-0.81)$ outperforming lactate $(P=0.01)$ and high-sensitivity $C$-reactive protein $(P<0.001)$. For prediction of gram-positive bacteremia, there was no difference between procalcitonin and lactate $(P=0.23)$ in the discriminative ability. Elevated procalcitonin level rendered a six-fold increased risk of positive gram-negative bacteremia with a diagnostic odds ratio of 6.44 (95\% confidence interval, 3.65-12.15), which showed no further improvement in two tests (elevated procalcitonin and lactate) or all-three test combinations. Nonetheless, for predicting gram-positive bacteria, the values of the diagnostic odds ratio were numerically lower in the single test procalcitonin $(1.89 ; 95 \%$ confidence interval, $1.11-3.33)$ than two- or three-test combination. In the sensitivity analysis, as a single test to predict unspecified, gram-negative and gram-positive bacteremia, procalcitonin performed even better in an expanded cohort of 2,234 adult patients in terms of the diagnostic odds ratio.

Discussions. For adult emergency patients, procalcitonin has an acceptable discriminative ability for 
bacterial blood culture and a better discriminative ability for gram-negative bacteremia when compared with lactate and high-sensitivity C-reactive protein. High-sensitivity C-reactive protein at a cutoff of 0.8 $\mathrm{mg} / \mathrm{dL}$ performed poorly for the prediction of positive bacterial culture. 
1 Diagnostic Value of Serum Procalcitonin, Lactate, and High2 sensitivity C-reactive Protein for Predicting Bacteremia in Adult

3 Patients in the Emergency Department

4

Chiung-Tsung Lin ${ }^{1,2}$, Jang-Jih Lu ${ }^{3,4}$, Yu-Ching Chen ${ }^{1,5}$, Victor C. Kok ${ }^{1,5,6, ~ *}$, Jorng-Tzong Horng $1,5,7$ *

7

1 Department of Bioinformatics and Medical Engineering, Asia University, Taichung 41354, Taiwan

2 Department of Laboratory Medicine, China Medical University Hospital, China Medical University, Taichung 40402, Taiwan

3 Department of Laboratory Medicine, Linkou Chang Gung Memorial Hospital, Taoyuan 333, Taiwan

4 Department of Medical Biotechnology and Laboratory Science, College of Medicine, Chang Gung University, Taoyuan 333, Taiwan

5 Disease Informatics Research Group, Asia University, Taichung 41354, Taiwan

6 Division of Medical Oncology, Department of Internal Medicine, Kuang Tien General

*Corresponding authors:

7 Department of Computer Science and Information Engineering, National Central University, Taoyuan 32001, Taiwan

Jorng-Tzong Horng and Victor C. Kok

Jorng-Tzong Horng, $\mathrm{PhD}$

Department of Computer Science and

Information Engineering

National Central University

Taoyuan 32001, Taiwan

Tel: +8863 4227151, ext. 35307

Fax: +886 34222681

horng@db.csie.ncu.edu.tw
Victor C. Kok, MMedSc, MD, Ph.D., FACP

Division of Medical Oncology

Department of Internal Medicine

Kuang Tien General Hospital

Taichung 43303, Taiwan

Tel: +886426625111 , ext. 2263

Fax: +886426655050

victorkok@asia.edu.tw 


\section{Abstract}

26

27

28

Background. Few studies compared the diagnostic value of procalcitonin with a combination of other tests including lactate and high-sensitivity C-reactive protein in the prediction of pathogenic bacteremia in emergency department adult patients.

Methods. We performed a retrospective cross-sectional study assessing the differences in performances of procalcitonin, lactate, high-sensitivity C-reactive protein and their combinations for predicting bacteremia in adult patients admitted to the emergency department. Sensitivity, specificity, overall accuracy, positive-test and negative-test likelihood, and diagnostic odds ratio with $95 \%$ confidence interval for each test combination were calculated for comparison. The receiver operating characteristic curve for every single test were compared using DeLong's method. We also performed a sensitivity analysis in two expanded patient cohorts to assess the discriminative ability of procalcitonin or test combination.

Results. A total of 886 patients fulfilled the selection criteria for this study forming the initial patient cohort. For prediction of gram-negative bacteremia, the receiver operating characteristic curves analyses revealed that procalcitonin at a cutoff of $0.5 \mathrm{ng} / \mathrm{mL}$ had the area under the receiver operating characteristic curve of 0.79 (95\% confidence interval, $0.76-0.81)$ outperforming lactate $(\mathrm{P}=0.01)$ and high-sensitivity $\mathrm{C}$-reactive protein $(\mathrm{P}<0.001)$. For prediction of gram-positive bacteremia, there was no difference between procalcitonin and lactate $(\mathrm{P}=0.23)$ in the discriminative ability. Elevated procalcitonin level rendered a six-fold increased risk of positive gram-negative bacteremia with a diagnostic odds ratio of 6.44 (95\% confidence interval, 3.65-12.15), which showed no further improvement in two tests (elevated procalcitonin and lactate) or all-three test combinations. Nonetheless, for predicting grampositive bacteria, the values of the diagnostic odds ratio were numerically lower in the single test 
48 procalcitonin $(1.89 ; 95 \%$ confidence interval, $1.11-3.33)$ than two- or three-test combination. In

49 the sensitivity analysis, as a single test to predict unspecified, gram-negative and gram-positive

50 bacteremia, procalcitonin performed even better in an expanded cohort of 2,234 adult patients in

51 terms of the diagnostic odds ratio.

52 Discussions. For adult emergency patients, procalcitonin has an acceptable discriminative ability

53 for bacterial blood culture and a better discriminative ability for gram-negative bacteremia when

54 compared with lactate and high-sensitivity C-reactive protein. High-sensitivity C-reactive protein

55 at a cutoff of $0.8 \mathrm{mg} / \mathrm{dL}$ performed poorly for the prediction of positive bacterial culture.

56 
57

58

59

60

61

62

63

64

65

66

67

68

69

70

71

72

73

74

75

76

77

\section{Introduction}

Bacterial bloodstream infection has been reported to have a rapid disease course, especially in patients admitted to the emergency department (ED) (Lindvig et al. 2016), and it is difficult to make an immediate and accurate diagnosis of bacteremia according to the clinical manifestations of patients. Sepsis is not easy to detect in the early phase, as the clinical manifestation could be latent or an exacerbation of a pre-existing condition, resulting in diagnostic difficulty (Castelli et al. 2004). Moreover, the mortality rate of blood-cultured patients in the medical ED has been reported to be high. In a cohort study, among patients who had blood cultures performed within $72 \mathrm{~h}$ of arrival to the medical ED, the overall 30-day mortality rate was $11 \%$ (Lindvig et al. 2016). The same study used a multivariate Cox model and demonstrated that bacteremia was one of the important prognostic factors of mortality among blood-cultured patients, with a hazard ratio of $1.4(95 \%$ confidence interval [CI], 1.1-1.8). The mortality could be reduced by early detection and initiation of appropriate antibiotics. The ED of a hospital is the first point of entry for the majority of emergency patients. Distinguishing bacteremic sepsis from non-infectious systemic inflammation is very challenging, and blood culture is considered as the standard diagnostic approach (Riedel 2012).

73 However, blood culture, including identification and drug sensitivity testing, requires at least $12-48 \mathrm{~h}$; therefore, early-stage diagnosis is very important. In the past two decades, procalcitonin has been adopted for early-stage diagnosis. Procalcitonin is a precursor hormone of calcitonin. It was found that when the body is stimulated by an inflammatory response, especially bacterial infection, different cells in multiple organs secrete procalcitonin (Linscheid et al. 2003; Nishikura 1999). Many studies have shown that procalcitonin has an excellent predictive ability for sepsis (Arora et al. 2017; Kibe et al. 2011; Nishikawa et al. 2017). 
Additionally, another study showed that there is a risk of bacteremia in patients with acute fever when the procalcitonin level is greater than $0.5 \mathrm{ng} / \mathrm{ml}$ (Kim et al. 2011). However, few studies argued against the usefulness of procalcitonin for predicting bloodstream infection in certain clinical settings (Aalto et al. 2004; Hoenigl et al. 2014).

Clinically, the combination of the C-reactive protein level and white blood cell count is commonly used as a basis for determining infection (Julian-Jimenez et al. 2015; Leli et al. 2014; Liu et al. 2017; Ljungstrom et al. 2017), although there is a lack of solid evidence. C-reactive protein is a marker of acute inflammation and is associated with non-specific inflammatory responses by the human body to infection or trauma. Blood C-reactive protein levels rapidly rise during such events.

Several studies in the past have examined the role in the risk stratification or the discriminative ability of lactate in the management of the bacterial sepsis in emergency patients (Freund et al. 2012; Ljungstrom et al. 2017; Shapiro et al. 2005). However, few studies have focused on the discriminative power of elevated lactate levels in blood to predict bacteremia in the literature. The results of the tests for procalcitonin, C-reactive protein, and lactate can be obtained within $1 \mathrm{~h}$, which may significantly shorten the time of decision-making for prescribing appropriate antibiotics if bacteremia is highly suggested by the results of the above tests, either singly or in combination.

This study focused on the differences in the performances of procalcitonin, lactate, highsensitivity C-reactive protein (Milone et al. 2014; Su et al. 2013; Windgassen et al. 2011; Yildiz et al. 2013) and their combinations for predicting positive blood bacterial culture in adult patients in the ED and analyzed the discriminative ability of these tests to predict positive blood culture for any non-contaminant bacteria, gram-positive bacteria (GPB), and gram-negative bacteria 
103 (GNB) (Nishikawa et al. 2016; Wang et al. 2016). The test efficiency of single items was 104 analyzed using the area under the receiver operating characteristic (ROC) curve (AUROC) 105 (Alemayehu \& Zou 2012). The method with the greatest AUROC was used as a judgment 106 standard for the relatively superior method among similar methods. 


\section{Materials \& Methods}

109 Collection of test data

110 This study used test data extracted from the dataset of a total of 41,358 blood bacterial

111 culture bottle records (aerobic and anaerobic bottles were counted separately) at the ED of a

112 medical center in central Taiwan between January 1, 2010 and December 31, 2010. In addition,

113 the information system of the hospital was used to collect patient test reports, including 7,879

114 lactate test records, 50,287 high-sensitivity C-reactive protein test records, and 3,037

115 procalcitonin test records. In total, 886 records with all tests performed in $24 \mathrm{~h}$ were identified 116 after examining the records.

118 Research ethics and personal information protection Hospital, Taichung, Taiwan (certificate number DMR-99-133). The study population included adult patients who were admitted to the Department of Emergency Medicine of China Medical

122 University Hospital and underwent septic workup in 2010. After identifying the study candidates, data files were de-identified. The whole process of data mining and data manipulation strictly complied with the Taiwan Personal Information Protection Act. The study

125 was classified as an exempt research study (number CMUH106-REC-003) by the Research

126 Ethics Committee of China Medical University Hospital, Taichung, Taiwan. The Ethics

127 Committee also waived the need for written or verbal informed consent from the patients. 
high-sensitivity C-reactive protein, and a value of $<0.8 \mathrm{mg} / \mathrm{dl}$ was used as the biological

132

133

134

135

136

137

138

139

140

141

142

143

144

145

146

147

148

149

150

151

152

reference. Traditional C-reactive protein and high-sensitivity C-reactive protein involve the same protein in the plasma, and they have been shown to represent the same entity (Windgassen et al. 2011). Lactate measurements were also analyzed using DXC-800, with a biological reference range of $4.5-19.8 \mathrm{mg} / \mathrm{dl}$. Procalcitonin testing was performed using mini VIDAS (BioMérieux, Marcy-l'Étoile, France) B.R.A.H.M.S procalcitonin analysis (USA 2008). The VIDAS

B.R.A.H.M.S procalcitonin is an automated test for determining human procalcitonin in human serum or plasma (lithium heparin) using the enzyme-linked fluorescent assay technique. The biological reference is $0.5 \mathrm{ng} / \mathrm{ml}$, and the functional sensitivity of the assay is $0.05 \mathrm{ng} / \mathrm{ml}$. Laboratory standard operating procedures were used for plasma/serum analyses of the above three items. A total of two blood culture sets (each set consists of one aerobic bottle and one anaerobic bottle) for each patient was considered mandatory. The volume of blood drawn for each culture set was $20 \mathrm{ml}$. Bacterial blood culture and analysis were performed using BD BACTECтм 9240 (Becton-Dickinson Diagnostic Instrument Systems, Baltimore, MD, USA). The BD BACTEC blood culture system is a fully automated microbiology growth and detection system designed to detect microbial growth in blood specimens.

Our research question was to examine the diagnostic value of elevated biomarkers using a cutoff at the upper limit of reference range (procalcitonin, $0.5 \mathrm{ng} / \mathrm{mL}$; lactate, $19.8 \mathrm{mg} / \mathrm{dL}$; and high-sensitivity C-reactive protein, $0.8 \mathrm{mg} / \mathrm{dL}$ ) for predicting bacteremia, not to derive an optimal cutoff for each single test to obtain the best discriminative power for bacteremia prediction. 
153 Definition of true bacteremia

154 Blood culture is a standard method for determining bloodstream infections, and culture

155 results can be as follows: 1) positive with a pathogen; 2) blood culture contamination, defined as

156 either less than two blood cultures positive for coagulase-negative staphylococci or diphtheroids

157 (catalase-positive gram-positive rods from multiple genera) (Leal et al. 2016) or time to

158 positivity for coagulase-negative staphylococci of more than $15 \mathrm{~h}$ (Schuetz et al., 2007); and 3)

159 negative without the culture of any bacteria from blood after more than 7 days.

160 True bacteremia was defined as growth of any significant, pathogenic bacterial species in

161 one or more sets of blood cultures consisting of aerobic and anaerobic bottles. Common skin

162 pathogens often considered as contaminants (namely, coagulase-negative Staphylococci, aerobic

163 and anaerobic diphtheroids, Micrococcus species, Propionibacterium species, or Bacillus

164 species) were excluded from this definition, except when the same species were isolated from at

165 least two consecutive blood cultures (Jaimes et al. 2004; Richter et al. 2002). Mixed cultures

166 were considered pathogenic when bacteria other than the contaminants were isolated.

Statistical analysis

The study by Riedel et al. (Riedel et al. 2011) was used as a reference. Tables 1-4 show

171 Fisher's exact test was used for blood bacterial culture results (positive, contamination, or

172 negative). The gold standard of sepsis diagnosis is a positive blood bacterial culture. ROC curves

173 refer to the curves obtained from the results of various tests and bacterial blood cultures. In this

174 study, ROC curves of GPC and GNB culture results and the three test items were obtained to

175 investigate which single diagnostic method is the most superior method among all the diagnostic 
176 methods. For pairwise comparisons of two correlated ROC curves, we used DeLong's variance

177 estimate to derive the standard error and identify the 95\% CI (DeLong et al. 1988).

178 In addition, we calculated the associations among all or some test values in single, paired, or

179 all test items (procalcitonin, high-sensitivity C-reactive protein, and lactate), which were greater

180 than the upper limit of the reference range, and blood bacterial culture results using traditional

181 indicators, such as sensitivity, specificity, overall accuracy (equivalent to diagnostic

182 effectiveness), positive-test likelihood, negative-test likelihood, preferred single indicator, and

183 diagnostic odds ratio, to investigate the effectiveness of various test combinations. A two-sided

$184 P$-value $<0.05$ was considered statistically significant. Statistical analyses were performed using

185 the StatsDirect statistical software.

186 We also performed a sensitivity analysis that assessed the discriminative ability of a test or

187 test combination in an expanded cohort of patients from the original dataset, in whom only the

188 procalcitonin test or two tests (procalcitonin + lactate) had been performed in addition to

189 standard blood culture. The diagnostic performance results from these two expanded cohorts of

190 patients are displayed along with the initial research cohort of 886 patients for comparison

191 purposes. Since the group sizes are important for the test performance, the prevalence of positive

192 blood culture in the two expanded cohorts are as follows: the expanded cohort that consisted of

193923 patients who had procalcitonin, lactate and blood cultures taken on the same day had a

194 prevalence of true bacteremia of $21.9 \%$ (202+/923). Another expanded cohort of 2,234 patients

195 who had procalcitonin test result and blood culture results had a prevalence of true bacteremia at

$196 \quad 15.5 \%(347+/ 2234)$.

197 
198

199

200

201

202

203

204

205

206

207

208

209

210

211

212

213

214

215

216

217

218

219

220

\section{Results}

Between January 2010 and December 2010, a total of 886 adult patients admitted to the ED underwent all three tests (procalcitonin, lactate, and high-sensitivity C-reactive protein) and at least two sets of blood culture within $24 \mathrm{~h}$ of the workup window. In this ED cohort, $22.2 \%$ $(197 / 886)$ of the patients showed positive results on blood culture. Blood cultures that had contaminants were noted in $3.05 \%(27 / 886)$ of the patients (Table 1). The cut-off values selected for the three tests were above the upper limit of the normal range $(\geq 0.5 \mathrm{ng} / \mathrm{ml}$ for procalcitonin, $\geq 19.8 \mathrm{mg} / \mathrm{dl}$ for lactate, and $\geq 0.8 \mathrm{mg} / \mathrm{dl}$ for high-sensitivity C-reactive protein).

We performed ROC curve analyses for every single test, procalcitonin, high-sensitivity Creactive protein, and lactate in all 886 adult patients to compare their discriminative power in the prediction of the blood culture positive for bacteria (Fig. 1), GNB (Fig. 2), and GPB (Fig. 3).

Wilcoxon estimate of the AUROC revealed the following results for the discriminative ability in positive blood culture prediction: procalcitonin $=0.72(95 \% \mathrm{CI}, 0.69-0.75)$; lactate $=0.69(95 \%$ CI, 0.66-0.72); high-sensitivity C-reactive protein $=0.56(95 \% \mathrm{CI}, 0.53-0.59)$. Pairwise comparisons of ROC curves using DeLong's methodology (DeLong et al. 1988) showed that the difference in the discriminative ability between either procalcitonin $(P<0.001)$ or lactate $(P<$ 0.001) and high-sensitivity C-reactive protein was statistically significant. There was no difference between procalcitonin and lactate $(P=0.30)$ (Fig. 1).

For GNB prediction, the Wilcoxon estimate of the AUROC revealed the following results: procalcitonin $=0.79(95 \% \mathrm{CI}, 0.76-0.81)$; lactate $=0.71(95 \% \mathrm{CI}, 0.68-0.74) ;$ high-sensitivity C-reactive protein $=0.60(95 \% \mathrm{CI}, 0.56-0.63)$. Pairwise comparisons of ROC curves showed that procalcitonin was statistically better than lactate $(P=0.01)$ and high-sensitivity C-reactive protein $(P<0.001)$, while lactate was statistically better than high-sensitivity $\mathrm{C}$-reactive protein 
$221(P=0.003)($ Fig. 2).

222 For GPB prediction, the Wilcoxon estimate of the AUROC revealed the following results:

223 procalcitonin $=0.61(95 \%$ CI, 0.57-0.64); lactate $=0.66(95 \%$ CI, $0.63-0.70) ;$ high-sensitivity

224 C-reactive protein $=0.50(95 \%$ CI, 0.46-0.54). Pairwise comparisons of ROC curves showed

225 that the difference between either procalcitonin $(P=0.003)$ or lactate $(P=0.001)$ and high-

226 sensitivity C-reactive protein was statistically significant. There was no difference between

227 procalcitonin and lactate $(P=0.23)$ (Fig. 3).

228 We assessed the discriminative ability results of single or combined tests to predict positive

229 blood culture (Table 2). With regard to single test items, the sensitivity, specificity, overall

230 accuracy, positive-test likelihood, negative-test likelihood, and diagnostic odds ratio for

231 procalcitonin were 81\% (95\% CI, 74\%-86\%), 47\% (95\% CI, 43\%-50\%), 54\% (95\% CI, 51\%-

$23257 \%), 1.51(95 \%$ CI, 1.36-1.66), 0.41 (95\% CI, 0.31-0.55), and 3.64 (95\% CI, 2.46-5.51),

233 respectively; those for lactate were 63\% (95\% CI, 0.56-0.7), 63\% (95\% CI, 59\%-66\%), 63\%

234 (95\% CI, 60\%-66\%), 1.71 (95\% CI, 1.47-1.96), 0.58 (95\% CI, 0.48-0.7), and 2.93 (95\% CI,

235 2.09-4.14), respectively; and those for high-sensitivity C-reactive protein were 88\% (95\% CI,

$23682 \%-92 \%), 11 \%$ (95\% CI, 9\%-14\%), 28\% (95\% CI, 25\%-31\%), 0.99 (95\% CI, 0.92-1.04), 1.09

237 (95\% CI, 0.71-1.66), and $0.91(95 \% \mathrm{CI}, 0.55-1.55 ; P=0.79)$, respectively (Table 2). With

238 regard to combined tests, the overall accuracy, positive-test likelihood, negative-test likelihood,

239 and diagnostic odds ratio for procalcitonin and lactate increases were $72 \%(95 \% \mathrm{CI}, 69 \%-75 \%$ ),

$2402.41(95 \% \mathrm{CI}, 1.98-2.91), 0.60$ (95\% CI, 0.51-0.70), and 3.98 (95\% CI, 2.81-5.63),

241 respectively. The results of the combined test were slightly better compared to those of the single

242 tests (Table 2). 
We assessed the discriminative ability results of single or combined tests to predict positive

244 GNB culture (Table 3). With regard to single test items, the sensitivity, specificity, overall

245 accuracy, positive-test likelihood, negative-test likelihood, and diagnostic odds ratio for

246 procalcitonin were 88\% (95\% CI, 81\%-93\%), 47\% (95\% CI, 43\%-50\%), 53\% (95\% CI, 50\%-

$24756 \%), 1.65$ (95\% CI, 1.49-1.81), 0.26 (95\% CI, 0.16-0.40), and 6.44 (95\% CI, 3.65-12.15),

248 respectively; those for lactate were 64\% (95\% CI, 55\%-73\%), 63\% (95\% CI, 59\%-66\%), 63\%

249 (95\% CI, 60\%-66\%), 1.73 (95\% CI, 1.46-2.02), 0.57 (95\% CI, 0.44-0.71), and 3.04 (95\% CI,

250 2.02-4.63), respectively; and those for high-sensitivity C-reactive protein were 90\% (95\% CI,

$25184 \%-95 \%), 11 \%(95 \%$ CI, 9\%-14\%), 23\% (95\% CI, 21\%-26\%), 1.02 (95\% CI, 0.94-1.07), 0.85

252 (95\% CI, 0.48-1.49), and 1.20 (95\% CI, 0.62-2.49; $P=0.70)$, respectively. With regard to

253 combined tests, the sensitivity, specificity, overall accuracy, positive-test likelihood, negative-

254 test likelihood, and diagnostic odds ratio for procalcitonin and lactate increases were 58\% (95\%

255 CI, 49\%-67\%), 78\% (95\% CI, 75\%-81\%), 75\% (95\% CI, 72\%-78\%), 2.64 (95\% CI, 2.14-3.22),

2560.54 (95\% CI, 0.43-0.65), and 4.9 (95\% CI, 3.24-7.45; $P<0.001)$, respectively. According to

257 the diagnostic effectiveness (accuracy) results, both procalcitonin and lactate increases provided

258 the highest overall accuracy for the prediction of GNB bacteremia (75\%) when compared to the

259 findings of the single tests of procalcitonin (53\%), lactate (63\%), and high-sensitivity C-reactive

260 protein $(23 \%)$. However, in terms of the diagnostic odds ratio, the single test of procalcitonin

261 showed better results than the combination (6.44 for procalcitonin alone vs. 4.9 for the

262 combination) (Table 3).

We further assessed the discriminative ability results of single or combined tests to predict

264 positive GPB culture (Table 4). With regard to single test items, the sensitivity, specificity,

265 overall accuracy, positive-test likelihood, negative-test likelihood, and diagnostic odds ratio for 
266 procalcitonin at a cutoff of $0.5 \mathrm{ng} / \mathrm{mL}$ were $68 \%(95 \% \mathrm{CI}, 57 \%-79 \%), 47 \%(95 \% \mathrm{CI}, 43 \%-$

$26750 \%), 49 \%(95 \%$ CI, 45\%-52\%), 1.28 (95\% CI, 1.06-1.49), 0.68 (95\% CI, 0.47-0.93), and 1.89

$268(95 \% \mathrm{CI}, 1.11-3.33 ; P=0.02)$, respectively; those for lactate were $63 \%(95 \% \mathrm{CI}, 51 \%-74 \%)$,

$26963 \%$ (95\% CI, 60\%-66\%), 63\% (95\% CI, 60\%-66\%), 1.7 (95\% CI, 1.36-2.04), 0.59 (95\% CI,

$270 \quad 0.42-0.78)$, and $2.88(95 \% \mathrm{CI}, 1.7-4.94 ; P<0.001)$, respectively; and those for high-sensitivity

271 C-reactive protein were 84\% (95\% CI, 73\%-91\%), 11\% (95\% CI, 9\%-14\%), 18\% (95\% CI,

272 15\%-21\%), 0.94 (95\% CI, 0.82-1.02), 1.47 (95\% CI, 0.83-2.49), and 0.64 (95\% CI, 0.32-1.37;

$273 P=0.25)$, respectively. With regard to combined tests, the overall accuracy and diagnostic odds

274 ratio for procalcitonin and lactate increases were $75 \%(95 \% \mathrm{CI}, 72 \%-78 \%)$ and $2.93(95 \% \mathrm{CI}$,

275 1.73-4.96; $P<0.001)$, respectively. The results of the combined test were slightly better

276 compared to those of the single tests (Table 4).

278 Validity analyses

279 We performed a further analysis to determine whether the discriminative powers of the 280 elevation of procalcitonin $(\geq 0.5 \mathrm{ng} / \mathrm{mL})$ in a single test and the elevations of procalcitonin and 281 lactate ( $\geq 19.8 \mathrm{mg} / \mathrm{dL})$ in a combined test for predicting positive blood bacterial culture or 282 positive GNB or GPB culture remain in an expanded cohort of similar patients (Supplementary

283 Table 1 and Supplementary Table 2). The discriminative ability of procalcitonin at a cutoff of 0.5 $284 \mathrm{ng} / \mathrm{mL}$ remained in an expanded cohort of 923 patients, with similar results for overall accuracy and diagnostic odds ratio between the single test and the combined test ( $72 \%$ vs. $72 \%$ in terms of 286 overall accuracy and 3.98 vs. 3.94 in terms of the diagnostic odds ratio for predicting positive 287 blood culture; $75 \%$ vs. $75 \%$ in terms of accuracy and 4.90 vs. 5.02 in terms of the diagnostic 288 odds ratio for predicting positive GNB culture; 75\% vs. 75\% in terms of accuracy and 2.93 vs. 
2892.75 in terms of the diagnostic odds ratio for predicting positive GPB culture (Supplementary 290 Table 2).

291 As a single test to predict bacteremia, the procalcitonin test performed even better in a 292 larger expanded cohort of 2,234 adult patients than in the initial cohort of 886 patients in terms 293 of overall accuracy and diagnostic odds ratio, $65 \%$ vs. $54 \%$ in terms of accuracy and 5.34 vs. 2943.64 in terms of the diagnostic odds ratio for predicting blood culture positivity; $65 \%$ vs. $53 \%$ in 295 terms of accuracy and 10.13 vs. 6.44 in terms of the diagnostic odds ratio for predicting positive 296 GNB culture; and $63 \%$ vs. $49 \%$ in terms of accuracy and 2.83 vs. 1.89 in terms of the diagnostic 297 odds ratio for predicting positive GPB culture (Supplementary Table 1).

298 The predictive performance of high-sensitivity C-reactive protein was consistently poor for 299 predicting positive blood culture, positive GNB culture, and positive GPB culture, according to 300 all three single global diagnostic indicators, namely AUROC analysis, diagnostic effectiveness 301 (accuracy), and diagnostic odds ratio. 
303

304

305

306

307

308

309

310

311

312

313

314

315

316

317

318

319

320

321

322

323

324

325

\section{Discussion}

In our study, with regard to the discriminative ability to predict bloodstream bacterial infection in adult patients admitted to the ED of a tertiary care medical center, the procalcitonin test was clinically useful to predict positive bacteremia and GNB bloodstream infection. This discriminative power was valid on assessment in a subsequently expanded cohort of 2,234 patients. In terms of a single global indicator, patients with elevated procalcitonin at a cutoff of $0.5 \mathrm{ng} / \mathrm{mL}$ have an at least six-fold increased diagnostic odds ratio for GNB bloodstream infection, as compared with normal procalcitonin results. The diagnostic odds ratio does not further improve when elevated lactate at a cutoff of $\geq 19.8 \mathrm{mg} / \mathrm{dL}$ is added to elevated procalcitonin. Elevated procalcitonin can predict positive GPB culture but with a much lower diagnostic odds ratio than that for positive GNB culture. High-sensitivity C-reactive protein performed poorly across all assessments of bloodstream infection, regardless of evaluation using any of the following diagnostic performance indicators: overall accuracy, AUROC analysis, or diagnostic odds ratio. Our data do not support the practice at the ED using highsensitivity C-reactive protein as a single test at a cutoff of $\geq 0.8 \mathrm{mg} / \mathrm{dL}$ to predict bloodstream bacterial infection.

Using multiple concurrent indicators, such as sensitivity, specificity, and positive-test or negative-test likelihood values, to compare the performance of competing diagnostic tests can be a disadvantage particularly if one test does not outperform the others on all indicators. The diagnostic odds ratio has been proposed as a single indicator of test performance especially in the era of evidence-based practice (Glas et al. 2003). In the stressful setting of the ED involving patient care with a presumptive diagnosis of bacterial bloodstream infection, the identification of the most appropriate test for antibiotic stewardship before the availability of blood culture 
results and notification of the chance of bacteremia to the patient and family after obtaining the result of the decision test are extremely important. In this study, the procalcitonin test was compared with conventional competing tests, such as high-sensitivity C-reactive protein and lactate, and it was shown that the procalcitonin test has better discrimination ability for blood culture results of contamination and negative bacterial growth, and its performance has better consistency with blood culture results of positive bacterial growth.

Our study incorporated three different single indicators of test performance for decisionmaking, namely, overall accuracy, diagnostic odds ratio, and AUROC analysis. Additionally, a negative-test likelihood of $<0.6$ can help indicate the clinical usefulness of a test. Therefore, one can compare the results of test performance by appreciating the results of the above indicators, and this is a strength of the present study.

We attempted to compare our results with those of other studies. Supplementary Table 3 presents our analysis of recent studies that reported procalcitonin as a single decision tool and used the diagnostic odds ratio as a single indicator of bloodstream infection. It is noteworthy that for predicting positive GNB culture, a positive procalcitonin test indicates a four- to sevenfold higher chance in terms of the diagnostic odds ratio when compared with a negative test result (diagnostic odds ratio $=4.14[95 \%$ CI, 2.00-8.58] in the study by Juutilainen et al.; 5.98 [95\% CI, 5.20-6.88] in the study by Oussalah et al. using a cutoff of $\geq 10 \mathrm{ng} / \mathrm{mL}$; and 6.44 [95\% CI, 3.65-12.15] in our study using a cutoff of $\geq 0.5 \mathrm{ng} / \mathrm{mL}$ ) (Juutilainen et al. 2011; Oussalah et al. 2015). The predictive power of a single procalcitonin test markedly dropped to around two- to four-fold for GPB (diagnostic odds ratio $=1.89$ [95\% CI, 1.11-3.33] in our study and 3.64 [95\% CI, 3.11-4.26] in the study by Oussalah et al. using a cutoff of $\geq 10$ $\mathrm{ng} / \mathrm{mL})$. 
It is worthwhile to look more deeply at the suitable cutoff of procalcitonin level aiming to

350

351

352

353

354

355

356

357

358

359

360

361

362

363

364

365

366

367

368

369

370

371

predict or rule out a positive bacteremia. In a prospective cohort study involving a total of 898 patients fulfilling the systemic inflammatory response syndrome (SIRS) criteria, at the cut-off of $0.1 \mathrm{ng} / \mathrm{mL}$, procalcitonin failed to predict bloodstream infection in $7 \%$ of patients (Hoenigl et al. 2014). If this cutoff is used to distinguish blood contamination from bloodstream infection due to coagulase-negative Staphylococci, procalcitonin test performed on the same day of blood culture collection had a sensitivity of $100 \%$, and a specificity of $80 \%$ for the diagnosis of bloodstream infection (Schuetz et al. 2007). Another retrospective single institution study reported that using procalcitonin to predict gram-negative bacteremia, at a cutoff of $>3.39$ $\mathrm{ng} / \mathrm{mL}$, the sensitivity would be $80 \%$, specificity $71 \%$, and the area under the curve 0.73 (Guo et al. 2015). A recent Japanese retrospective study involving 1,331 adults with suspicious bloodstream infections derived an optimal cutoff of procalcitonin for discriminating positive blood cultures from negative ones; with the cutoff at $0.9 \mathrm{ng} / \mathrm{mL}$, the sensitivity, specificity, positive predictive value, and negative predictive value were $71.9 \%, 69.1 \%, 24.5 \%$, and $94.6 \%$, respectively (Hattori et al. 2014). Another South Korean retrospective study involving 300 patients with fever, 58 of them had positive blood culture, when using procalcitonin level at a cut-off value of $0.5 \mathrm{ng} / \mathrm{mL}$, the sensitivity and specificity were $74.2 \%$ and $70.1 \%$, respectively. This Korean study also demonstrates that when procalcitonin level is $<0.4 \mathrm{ng} / \mathrm{mL}$, it accurately rules out the diagnosis of bacteremia (Kim et al. 2011). In a Swiss prospective case-control study accruing 200 hospitalized adults, at a cut-off of $0.5 \mathrm{ng} / \mathrm{mL}$, the sensitivity of procalcitonin was $56 \%$, and the specificity was $83 \%$ to discriminate positive blood cultures from negative blood cultures (Liaudat et al. 2001). Physicians frequently place the bloodstream infections on the top of the differential diagnoses when a patient presents with the SIRS defined as two or 
372 more abnormalities in temperature, heart rate, respiration, or white blood cell count (Levy et al.

373 2003). A recent study demonstrates that the performance of procalcitonin to predict a

374 bloodstream infection was not affected by the SIRS status. Procalcitonin of $<0.1 \mathrm{ng} / \mathrm{mL}$ had a

375 negative predictive value of 97.4 and $96.2 \%$ for bloodstream infection in the SIRS-negative and

376 SIRS-positive patients, respectively (Arora et al. 2017). Using a cutoff at the upper limit of

377 reference range for all three biomarkers, the generalizability of our study results will be more

378 easily applied to the real-world practice in the emergency department.

379 Interestingly, elevated lactate at a cutoff of $\geq 19.8 \mathrm{mg} / \mathrm{dL}$ is better than elevated

380 procalcitonin in terms of producing a higher diagnostic odds ratio with a two- to three-fold

381 increase in the prediction of positive GPB culture. This association has not been reported in

382 previous studies. In our study, lactate combined with procalcitonin was found to have a better

383 detection capability than high-sensitivity C-reactive protein, and this result may decrease the

384 use of antibiotics in this aspect, when practicing physicians in the ED, who frequently depend

385 on high-sensitivity C-reactive protein to help with the decision to prescribe antibiotics

386 (antibiotic stewardship), make use of decision tools, such as lactate, instead of high-sensitivity

387 C-reactive protein.

388 From the results of single tests, pairwise test combinations, and blood culture, we noted 389 some important features. First, test combinations may not have better detection ability than a 390 single test. Second, for test combinations, the combination with an increase in a single factor 391 has a higher odds ratio and lower negative-test likelihood than the combination with increases in both factors. Third, elevated lactate and/or procalcitonin show a lower negative-test likelihood and higher odds ratio. Finally, for predicting GNB infection, procalcitonin has better

394 detection capability, and the diagnostic odds ratio does not improve when procalcitonin is used 
395

396

397

398

399

400

401

402

403

404

405

406

407

408

409

410

411

412

413

414

415

416

in combination with lactate. To the best of our knowledge, there are few published works investigating whether a combination of tests such as the combination of procalcitonin + lactate or procalcitonin + C-reactive protein or all three of them would outperform procalcitonin as a single test in prediction of the bloodstream infections in adult patients in the setting of emergency department care (Ljungstrom et al. 2017). For prediction of bacteremia in adult patients suspected with sepsis admitted to the emergency department at Skaraborg Hospital, Sweden, elevated procalcitonin $(\mathrm{AUC}=0.74 ; 95 \% \mathrm{CI} 0.70-0.78)$ performs as good as the composite four biomarkers [procalcitonin, lactate, C-reactive protein and neutrophil and lymphocyte count $(\mathrm{NLCR})](\mathrm{AUC}=0.78 ; 95 \% \mathrm{CI} 0.74-0.81)(\mathrm{P}=0.06)($ Ljungstrom et al 2017). This group of patients had a very high prevalence of verified bacterial infection, at $55.6 \%(874 / 1,572)$.

The present study has some limitations. First, this study only collected data of samples from an academic medical center in central Taiwan, and this could have led to sampling bias. The results from this study may not apply to the ED of other hospitals. Second, during enrollment in this study, the number of cases that fulfilled the enrollment criteria was not large; therefore, this study only classified bacteria as GPB and GNB. Readers are again reminded here that our study assesses predictors of blood culture positivity, but not of sepsis. In further analysis, the sample size should be expanded to increase the credibility of the results. Third, as this study only examined adult emergency patients in a medical center in central Taiwan, the results may be affected by factors such as prior use of antibiotics by the patient, underlying disease status, conduction of tests simultaneously, improper sterilization during blood sample collection resulting in contamination, and insufficient blood collection resulting in negative results. 
417 Subsequent studies could consider including specialty-specific and clinical signs (e.g.,

418 temperature, blood pressure, arterial blood gas, leukocyte count, breathing rate, and heart rate).

\section{Conclusions}

421 For adult emergency patients, procalcitonin has an acceptable discriminative ability for

422 bacterial blood culture and a better discriminative ability for positive GNB culture when

423 compared with lactate and high-sensitivity C-reactive protein. Although blood culture may be

424 positive, the patient may not have sepsis; therefore, accurate discrimination of contamination is

425 important to ED physicians for treatment purposes. In terms of a single global indicator, patients

426 with elevated procalcitonin at a cutoff of $0.5 \mathrm{ng} / \mathrm{mL}$ harbor an at least six-fold increased

427 diagnostic odds ratio for GNB bloodstream infection, when compared with a normal

428 procalcitonin result. The diagnostic odds ratio does not further improve when elevated lactate at

429 a cutoff of $19.8 \mathrm{mg} / \mathrm{dL}$ is added to elevated procalcitonin. Elevated procalcitonin can predict

430 positive GPB culture with a much lower diagnostic odds ratio than that for positive GNB culture.

431 High-sensitivity C-reactive protein performed poorly for the prediction of positive bacterial

432 culture. The development of new and effective testing methods will be beneficial for institutions

433 with limited medical resources. Future studies should be performed to determine whether both

434 new and old methods can be used in combination. It is worth mentioning that high-sensitivity C-

435 reactive protein does not show significance for distinguishing blood bacterial culture results of

436 contamination and positivity. 
439 We thank Crimson Interactive Pvt. Ltd. (Enago)-www.enago.tw for their assistance in 440 manuscript editing.

441 
442

443

444

445

446

447

448

449

450

451

452

453

454

455

456

457

458

459

460

461

462

463

464

465

466

467

468

469

470

471

472

473

474

475

476

477

478

479

480

481

482

483

484

485

486

487
References

Aalto $\mathrm{H}$, Takala A, Kautiainen $\mathrm{H}$, and Repo H. 2004. Laboratory markers of systemic inflammation as predictors of bloodstream infection in acutely ill patients admitted to hospital in medical emergency. Eur J Clin Microbiol Infect Dis 23:699-704. 10.1007/s10096-004-1191-8

Alemayehu D, and Zou KH. 2012. Applications of ROC analysis in medical research: recent developments and future directions. Acad Radiol 19:1457-1464. 10.1016/j.acra.2012.09.006

Arora R, Campbell JP, Simon G, and Sahni N. 2017. Does serum procalcitonin aid in the diagnosis of bloodstream infection regardless of whether patients exhibit the systemic inflammatory response syndrome? Infection 45:291-298. 10.1007/s15010-016-0965-0

Castelli GP, Pognani C, Meisner M, Stuani A, Bellomi D, and Sgarbi L. 2004. Procalcitonin and C-reactive protein during systemic inflammatory response syndrome, sepsis and organ dysfunction. Crit Care 8:R234-242. 10.1186/cc2877

DeLong ER, DeLong DM, and Clarke-Pearson DL. 1988. Comparing the areas under two or more correlated receiver operating characteristic curves: a nonparametric approach. Biometrics 44:837-845.

Freund Y, Delerme S, Goulet H, Bernard M, Riou B, and Hausfater P. 2012. Serum lactate and procalcitonin measurements in emergency room for the diagnosis and risk-stratification of patients with suspected infection. Biomarkers 17:590-596. 10.3109/1354750X.2012.704645

Glas AS, Lijmer JG, Prins MH, Bonsel GJ, and Bossuyt PMM. 2003. The diagnostic odds ratio: a single indicator of test performance. Journal of Clinical Epidemiology 56:1129-1135. 10.1016/s08954356(03)00177-x

Guo SY, Zhou Y, Hu QF, Yao J, and Wang H. 2015. Procalcitonin is a marker of gram-negative bacteremia in patients with sepsis. Am J Med Sci 349:499-504. 10.1097/maj.0000000000000477

Hattori T, Nishiyama H, Kato H, Ikegami S, Nagayama M, Asami S, Usami M, Suzuki M, Murakami I, Minoshima M, Yamagishi $H$, and Yuasa N. 2014. Clinical value of procalcitonin for patients with suspected bloodstream infection. Am J Clin Pathol 141:43-51. 10.1309/ajcp4gv7zfdtangc

Hoenigl M, Raggam RB, Wagner J, Prueller F, Grisold AJ, Leitner E, Seeber K, Prattes J, Valentin T, ZollnerSchwetz I, Schilcher G, and Krause R. 2014. Procalcitonin fails to predict bacteremia in SIRS patients: a cohort study. Int J Clin Pract 68:1278-1281. 10.1111/ijcp.12474

Jaimes F, Arango C, Ruiz G, Cuervo J, Botero J, Velez G, Upegui N, and Machado F. 2004. Predicting bacteremia at the bedside. Clin Infect Dis 38:357-362. 10.1086/380967

Julian-Jimenez A, Gutierrez-Martin P, Lizcano-Lizcano A, Lopez-Guerrero MA, Barroso-Manso A, and Heredero-Galvez E. 2015. Usefulness of procalcitonin and C-reactive protein for predicting bacteremia in urinary tract infections in the emergency department. Actas Urol Esp 39:502-510. 10.1016/j.acuro.2015.03.003

Juutilainen A, Hamalainen S, Pulkki K, Kuittinen T, Nousiainen T, Jantunen E, and Koivula I. 2011. Biomarkers for bacteremia and severe sepsis in hematological patients with neutropenic fever: multivariate logistic regression analysis and factor analysis. Leuk Lymphoma 52:2349-2355. 10.3109/10428194.2011.597904

Kibe S, Adams K, and Barlow G. 2011. Diagnostic and prognostic biomarkers of sepsis in critical care. J Antimicrob Chemother 66 Suppl 2:ii33-40. 10.1093/jac/dkq523

Kim MH, Lim G, Kang SY, Lee WI, Suh JT, and Lee HJ. 2011. Utility of procalcitonin as an early diagnostic marker of bacteremia in patients with acute fever. Yonsei Med J 52:276-281. 10.3349/ymj.2011.52.2.276

Leal SM, Jr., Jones M, and Gilligan PH. 2016. Clinical Significance of Commensal Gram-Positive Rods Routinely Isolated from Patient Samples. J Clin Microbiol 54:2928-2936. 10.1128/jcm.01393-16

PeerJ reviewing PDF | (2017:07:19485:2:0:NEW 29 Oct 2017) 
488

489

490

491

492

493

494

495

496

497

498

499

500

501

502

503

504

505

506

507

508

509

510

511

512

513

514

515

516

517

518

519

520

521

522

523

524

525

526

527

528

529

530

531

532

533

534

535

Leli C, Cardaccia A, Ferranti M, Cesarini A, D'Alo F, Ferri C, Cenci E, and Mencacci A. 2014. Procalcitonin better than C-reactive protein, erythrocyte sedimentation rate, and white blood cell count in predicting DNAemia in patients with sepsis. Scand J Infect Dis 46:745-752. 10.3109/00365548.2014.936493

Levy MM, Fink MP, Marshall JC, Abraham E, Angus D, Cook D, Cohen J, Opal SM, Vincent JL, and Ramsay G. 2003. 2001 SCCM/ESICM/ACCP/ATS/SIS International Sepsis Definitions Conference. Crit Care Med 31:1250-1256. 10.1097/01.ccm.0000050454.01978.3b

Liaudat S, Dayer E, Praz G, Bille J, and Troillet N. 2001. Usefulness of procalcitonin serum level for the diagnosis of bacteremia. Eur J Clin Microbiol Infect Dis 20:524-527.

Lindvig KP, Nielsen SL, Henriksen DP, Jensen TG, Kolmos HJ, Pedersen C, Vinholt PJ, and Lassen AT. 2016. Mortality and prognostic factors of patients who have blood cultures performed in the emergency department: a cohort study. Eur J Emerg Med 23:166-172. 10.1097/mej.0000000000000250

Linscheid P, Seboek D, Nylen ES, Langer I, Schlatter M, Becker KL, Keller U, and Muller B. 2003. In vitro and in vivo calcitonin I gene expression in parenchymal cells: a novel product of human adipose tissue. Endocrinology 144:5578-5584. 10.1210/en.2003-0854

Liu HH, Zhang MW, Guo JB, Li J, and Su L. 2017. Procalcitonin and C-reactive protein in early diagnosis of sepsis caused by either Gram-negative or Gram-positive bacteria. Ir J Med Sci 186:207-212. 10.1007/s11845-016-1457-z

Ljungstrom L, Pernestig AK, Jacobsson G, Andersson R, Usener B, and Tilevik D. 2017. Diagnostic accuracy of procalcitonin, neutrophil-lymphocyte count ratio, C-reactive protein, and lactate in patients with suspected bacterial sepsis. PLoS One 12:e0181704. 10.1371/journal.pone.0181704

Milone MT, Kamath AF, and Israelite CL. 2014. Converting between high- and low-sensitivity C-reactive protein in the assessment of periprosthetic joint infection. J Arthroplasty 29:685-689. 10.1016/j.arth.2013.09.015

Nishikawa H, Shirano M, Kasamatsu Y, Morimura A, lida K, Kishi T, Goto T, Okamoto S, and Ehara E. 2016. Comparative usefulness of inflammatory markers to indicate bacterial infection-analyzed according to blood culture results and related clinical factors. Diagn Microbiol Infect Dis 84:6973. 10.1016/j.diagmicrobio.2015.09.015

Nishikawa H, Shirano M, Kasamatsu Y, Morimura A, lida K, Kishi T, Goto T, Okamoto S, and Ehara E. 2017. Comparison between procalcitonin and C-reactive protein in predicting bacteremias and confounding factors: a case-control study. Clin Chem Lab Med 55:1043-1052. 10.1515/cclm2016-0705

Nishikura T. 1999. Procalcitonin (PCT) production in a thyroidectomized patient. Intensive Care Med 25:1031.

Oussalah A, Ferrand J, Filhine-Tresarrieu P, Aissa N, Aimone-Gastin I, Namour F, Garcia M, Lozniewski A, and Gueant JL. 2015. Diagnostic Accuracy of Procalcitonin for Predicting Blood Culture Results in Patients With Suspected Bloodstream Infection: An Observational Study of 35,343 Consecutive Patients (A STROBE-Compliant Article). Medicine (Baltimore) 94:e1774. 10.1097/md.0000000000001774

Richter SS, Beekmann SE, Croco JL, Diekema DJ, Koontz FP, Pfaller MA, and Doern GV. 2002. Minimizing the workup of blood culture contaminants: implementation and evaluation of a laboratorybased algorithm. J Clin Microbiol 40:2437-2444.

Riedel S. 2012. Procalcitonin and the role of biomarkers in the diagnosis and management of sepsis. Diagn Microbiol Infect Dis 73:221-227. 10.1016/j.diagmicrobio.2012.05.002

Riedel S, Melendez JH, An AT, Rosenbaum JE, and Zenilman JM. 2011. Procalcitonin as a marker for the detection of bacteremia and sepsis in the emergency department. Am J Clin Pathol 135:182-189. 10.1309/ajcp1mfyinqlecv2 
536

537

538

539

540

541

542

543

544

545

546

547

548

549

550

551

552

553

554
Schuetz P, Mueller B, and Trampuz A. 2007. Serum procalcitonin for discrimination of blood contamination from bloodstream infection due to coagulase-negative staphylococci. Infection 35:352-355. 10.1007/s15010-007-7065-0

Shapiro NI, Howell MD, Talmor D, Nathanson LA, Lisbon A, Wolfe RE, and Weiss JW. 2005. Serum lactate as a predictor of mortality in emergency department patients with infection. Ann Emerg Med 45:524-528. 10.1016/j.annemergmed.2004.12.006

Su YJ, Liao SC, Cheng BC, Hwang JC, and Chen JB. 2013. Increasing high-sensitive C-reactive protein level predicts peritonitis risk in chronic peritoneal dialysis patients. BMC Nephrol 14:185. 10.1186/1471-2369-14-185

USA B. 2008. BRAHMS PCT sensitive KRYPTOR Instruction Manual (version 4.0us).

Wang T, Cui YL, Lin ZF, and Chen DC. 2016. Comparative Study of Plasma Endotoxin with Procalcitonin Levels in Diagnosis of Bacteremia in Intensive Care Unit Patients. Chin Med J (Engl) 129:417-423. 10.4103/0366-6999.176064

Windgassen EB, Funtowicz L, Lunsford TN, Harris LA, and Mulvagh SL. 2011. C-reactive protein and highsensitivity C-reactive protein: an update for clinicians. Postgrad Med 123:114-119. 10.3810/pgm.2011.01.2252

Yildiz B, Poyraz H, Cetin N, Kural N, and Colak O. 2013. High sensitive C-reactive protein: a new marker for urinary tract infection, VUR and renal scar. Eur Rev Med Pharmacol Sci 17:2598-2604. 


\section{Legends of Figures and Tables}

556 Figure 1. The receiver operating characteristic (ROC) curves for procalcitonin (PCT), high-sensitivity C-

557 reactive protein (hs-CRP), and lactate (LAC) results relative to the "gold standard" of blood culture

558 positive for bacteria in a total of 886 adult patients admitted to the emergency department. Wilcoxon

559 estimates of the area under the ROC curve are as follows: $\mathrm{PCT}=0.72(95 \% \mathrm{CI}, 0.69-0.75) ; \mathrm{LAC}=0.69$

560 (95\% CI, 0.66-0.72); CRP $=0.56(95 \% \mathrm{CI}, 0.53-0.59)$. Pairwise comparisons of ROC curves show that

561 the difference between either PCT $(P<0.001)$ or LAC $(P=0.001)$ and hs-CRP is statistically significant.

562 There is no difference between PCT and LAC $(P=0.30)$.

563

564

Figure 2. The receiver operating characteristic (ROC) curves for procalcitonin (PCT), high-sensitivity Creactive protein (hs-CRP), and lactate (LAC) results relative to the "gold standard" of blood culture positive for gram-negative bacteria in a total of 815 adult patients admitted to the emergency department. Wilcoxon estimates of the area under the ROC curve are as follows: PCT $=0.79(95 \% \mathrm{CI}, 0.76-0.81)$; statistically better than hs-CRP $(P=0.003)$.

571

572 Figure 3. The receiver operating characteristic (ROC) curves for procalcitonin (PCT), high-sensitivity Creactive protein (hs-CRP), and lactate (LAC) results relative to the "gold standard" of blood culture

574 positive for gram-positive bacteria in a total of 762 adult patients admitted to the emergency department.

575 Wilcoxon estimates of the area under the ROC curve are as follows: PCT $=0.61(95 \%$ CI, 0.57-0.64);

$\mathrm{LAC}=0.66(95 \% \mathrm{CI}, 0.63-0.70) ; \mathrm{CRP}=0.50(95 \% \mathrm{CI}, 0.46-0.54)$. Pairwise comparisons of ROC curves

577 show that the difference between either PCT $(P=0.003)$ or LAC $(P=0.001)$ and hs-CRP is statistically

578 significant. There is no difference between PCT and LAC $(P=0.23)$. 
580 Table 1. Procalcitonin, high-sensitivity C-reactive protein (hs-CRP), and lactate levels versus blood

581 culture results in 886 adult patients admitted to the emergency department, who underwent workup for

582 presumed bacteremia or sepsis.

583

584 Table 2. Diagnostic variables associated with elevation of either procalcitonin (PCT $\geq 0.5 \mathrm{ng} / \mathrm{ml}$ ), blood

585 lactate ( $\mathrm{LAC} \geq 19.8 \mathrm{mg} / \mathrm{dl}$ ), or high-sensitivity C-reactive protein (hs-CRP $\geq 0.8 \mathrm{mg} / \mathrm{dl}$ ), two variables, and 586 all variables for predicting positive blood culture.

587

588 Table 3. Diagnostic variables associated with elevation of either procalcitonin (PCT $\geq 0.5 \mathrm{ng} / \mathrm{ml}$ ), blood

589 lactate (LAC $\geq 19.8 \mathrm{mg} / \mathrm{dl}$ ), or high-sensitivity C-reactive protein (hs-CRP $\geq 0.8 \mathrm{mg} / \mathrm{dl}$ ), two variables, and 590 all variables for predicting blood culture positive for gram-negative bacteria.

591

592

Table 4. Diagnostic variables associated with elevation of either procalcitonin (PCT $\geq 0.5 \mathrm{ng} / \mathrm{ml}$ ), blood

593

lactate (LAC $\geq 19.8 \mathrm{mg} / \mathrm{dl}$ ), or high-sensitivity C-reactive protein (hs-CRP $\geq 0.8 \mathrm{mg} / \mathrm{dl}$ ), two variables, and

594 all variables for predicting blood culture positive for gram-positive bacteria.

595

596 Supplementary Table 1. Results of the examination of the ability of procalcitonin (PCT) elevation $(\geq 0.5$

$597 \mathrm{ng} / \mathrm{ml}$ ) to continue to predict positive blood culture and blood culture positive for gram-negative bacteria

598 (GNB) or gram-positive bacteria (GPB) in an expanded cohort of similar patients.

599

600 Supplementary Table 2 . Results of the examination of the ability of procalcitonin (PCT) elevation $(\geq 0.5$

$601 \mathrm{ng} / \mathrm{ml}$ ) and lactate (LAC) elevation ( $\geq 19.8 \mathrm{mg} / \mathrm{dl}$ ) to continue to predict positive blood culture and blood

602 culture positive for gram-negative bacteria (GNB) or gram-positive bacteria (GPB) in an expanded cohort

603 of similar patients.

604 
605 Supplementary Table 3. Analysis of studies reporting procalcitonin (PCT) as a single decision tool and 606 diagnostic odds ratio (DOR) as a single indicator of bloodstream infection. Please note that studies cited 607 in the table used different cut-off values of PCT. 


\section{Figure 1}

Figure 1. The ROC curves for procalcitonin, high-sensitivity C-reactive protein, and lactate results relative to the "gold standard" of blood culture positive for bacteria.

The receiver operating characteristic (ROC) curves for procalcitonin (PCT), high-sensitivity Creactive protein (hs-CRP), and lactate (LAC) results relative to the "gold standard" of blood culture positive for bacteria in a total of 886 adult patients admitted to the emergency department. Wilcoxon estimates of the area under the ROC curve are as follows: PCT $=0.72$ $(95 \% \mathrm{Cl}, 0.69-0.75) ; \mathrm{LAC}=0.69(95 \% \mathrm{Cl}, 0.66-0.72) ; \mathrm{CRP}=0.56(95 \% \mathrm{Cl}, 0.53-0.59)$. Pairwise comparisons of ROC curves show that the difference between either PCT $(P<0.001)$ or LAC ( $P=0.001)$ and hs-CRP is statistically significant. There is no difference between PCT and LAC $(P=0.30)$. 


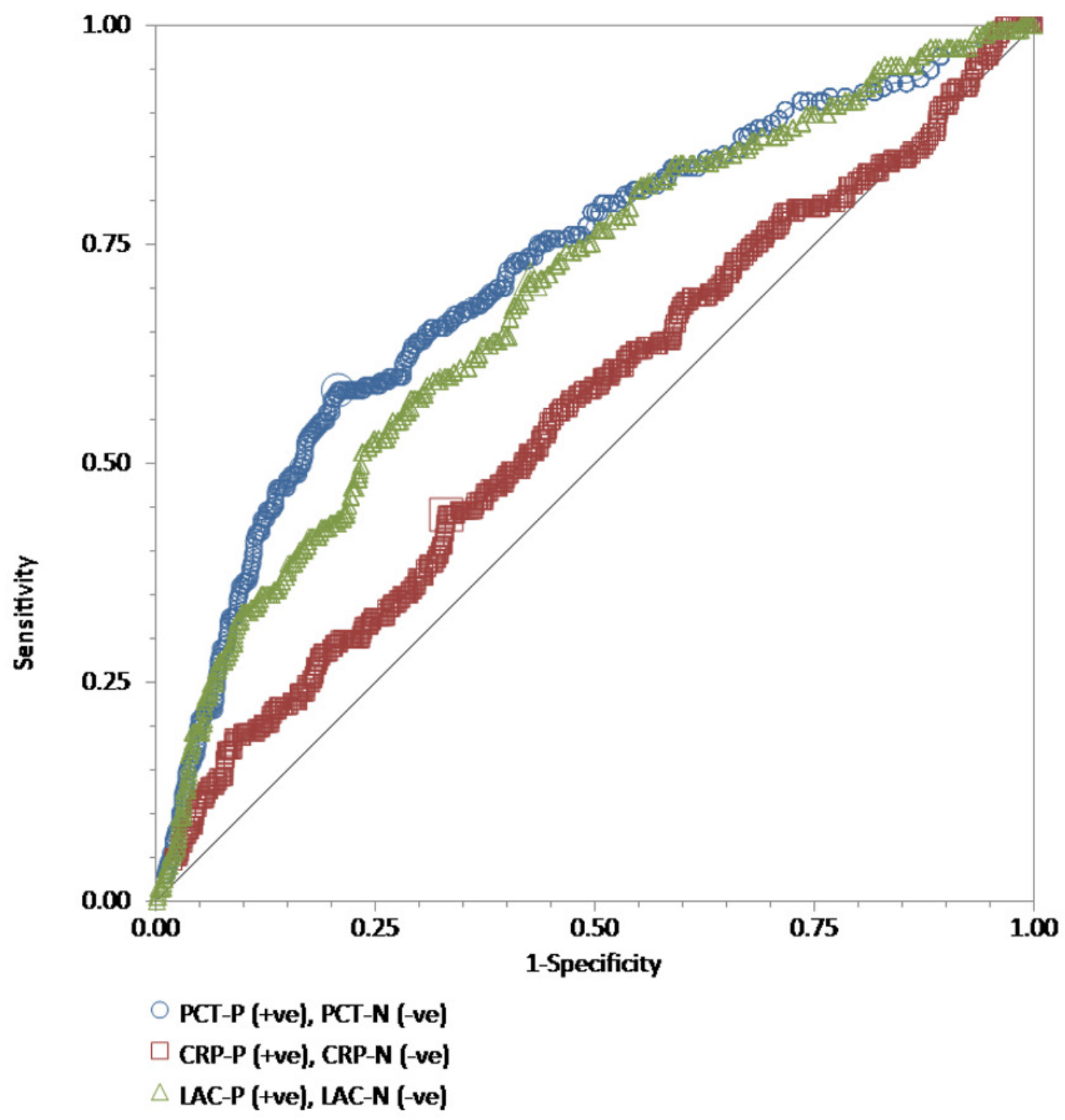




\section{Figure 2}

Figure 2. The ROC curves for procalcitonin, high-sensitivity C-reactive protein, and lactate results relative to the "gold standard" of blood culture positive for gramnegative bacteria.

The receiver operating characteristic (ROC) curves for procalcitonin (PCT), high-sensitivity Creactive protein (hs-CRP), and lactate (LAC) results relative to the "gold standard" of blood culture positive for gram-negative bacteria in a total of 815 adult patients admitted to the emergency department. Wilcoxon estimates of the area under the ROC curve are as follows: $\mathrm{PCT}=0.79(95 \% \mathrm{Cl}, 0.76-0.81) ; \mathrm{LAC}=0.71(95 \% \mathrm{Cl}, 0.68-0.74) ; \mathrm{CRP}=0.60(95 \% \mathrm{Cl}$, 0.56-0.63). Pairwise comparisons of ROC curves show that PCT was statistically better than LAC $(P=0.01)$ and hs-CRP $(P<0.001)$, while LAC was statistically better than hs-CRP $(P=$ 0.003). 







\section{Figure 3}

Figure 3. The ROC curves for procalcitonin, high-sensitivity C-reactive protein, and lactate results relative to the "gold standard" of blood culture positive for gram-positive bacteria.

The receiver operating characteristic (ROC) curves for procalcitonin (PCT), high-sensitivity Creactive protein (hs-CRP), and lactate (LAC) results relative to the "gold standard" of blood culture positive for gram-positive bacteria in a total of 762 adult patients admitted to the emergency department. Wilcoxon estimates of the area under the ROC curve are as follows: $\mathrm{PCT}=0.61(95 \% \mathrm{Cl}, 0.57-0.64) ; \mathrm{LAC}=0.66(95 \% \mathrm{Cl}, 0.63-0.70) ; \mathrm{CRP}=0.50(95 \% \mathrm{Cl}$, 0.46-0.54). Pairwise comparisons of ROC curves show that the difference between either PCT $(P=0.003)$ or LAC $(P=0.001)$ and hs-CRP is statistically significant. There is no difference between PCT and LAC $(P=0.23)$. 







\section{Table $\mathbf{1}$ (on next page)}

Table 1. Procalcitonin, hs-CRP, and lactate levels versus blood culture results in 886 adult patients admitted to the ED, who underwent workup for presumed bacteremia or sepsis. 
1 Table 1. Procalcitonin, high-sensitivity C-reactive protein (hs-CRP), and lactate levels versus

2 blood culture results in 886 adult patients admitted to the emergency department, who

3 underwent workup for presumed bacteremia or sepsis.

\begin{tabular}{|c|c|c|c|}
\hline Test Item & \multicolumn{2}{|c|}{ Blood Culture Results } & \multirow[t]{3}{*}{ Total } \\
\hline Procalcitonin & Positive with & Negative & \\
\hline Level (ng/mL) & Bacteria & & \\
\hline$\geq 0.5$ & 159 & 368 & 527 \\
\hline$<0.5$ & 38 & 321 & 359 \\
\hline Total & 197 & 689 & 886 \\
\hline $\begin{array}{l}\text { hs-CRP Level } \\
(\mathrm{mg} / \mathrm{dL})\end{array}$ & $\begin{array}{l}\text { Positive with } \\
\text { Bacteria }\end{array}$ & Negative & \\
\hline$\geq 0.8$ & 173 & 612 & 785 \\
\hline$<0.8$ & 24 & 77 & 101 \\
\hline Total & 197 & 689 & 886 \\
\hline $\begin{array}{l}\text { Lactate Level } \\
(\mathrm{mg} / \mathrm{dL})\end{array}$ & $\begin{array}{l}\text { Positive with } \\
\text { Bacteria }\end{array}$ & Negative & \\
\hline$\geq 19.8$ & 125 & 256 & 381 \\
\hline$<19.8$ & 72 & 433 & 505 \\
\hline Total & 197 & 689 & 886 \\
\hline
\end{tabular}

4 Cultures that regarded as a contaminant account for 3\% (27/886) in this cohort of 886 patients. A

5 statistically significant difference $(p<0.0001)$ was observed for procalcitonin levels according to

6 patients' blood culture results (positive vs. negative). The blood culture result type (positive vs. negative)

7 did not differ between patients with hs-CRP results $(p=0.79)$. A statistically significant difference $(p$

$8<0.0001$ ) was observed for lactate results according to patients' blood culture results (positive vs.

9 negative). 


\section{Table 2 (on next page)}

Table 2. Diagnostic variables associated with either single or combined tests for predicting positive blood culture.

Diagnostic variables associated with elevation of either procalcitonin (PCT $\geq 0.5 \mathrm{ng} / \mathrm{ml}$ ), blood lactate (LAC $\geq 19.8 \mathrm{mg} / \mathrm{dl}$ ), or high-sensitivity C-reactive protein ( $\mathrm{hs}-\mathrm{CRP} \geq 0.8 \mathrm{mg} / \mathrm{dl}$ ), two variables, and all variables for predicting positive blood culture. 
1 Table 2. Diagnostic variables associated with elevation of either procalcitonin (PCT $\geq 0.5 \mathrm{ng} / \mathrm{ml}$ ), 2 blood lactate (LAC $\geq 19.8 \mathrm{mg} / \mathrm{dl}$ ), or high-sensitivity C-reactive protein (hs-CRP $\geq 0.8 \mathrm{mg} / \mathrm{dl}$ ), two 3 variables, and all variables for predicting positive blood culture.

\begin{tabular}{|c|c|c|c|c|c|c|c|}
\hline Patte & $\begin{array}{l}\text { Sensitivity } \\
(95 \% \\
\text { Confidence } \\
\text { Interval, } \\
\text { CI) }\end{array}$ & $\begin{array}{l}\text { Specificity } \\
(95 \% \text { CI) }\end{array}$ & $\begin{array}{l}\text { Overall } \\
\text { Accuracy (= } \\
\text { Diagnostic } \\
\text { Effectiveness) } \\
(95 \% \text { CI) }\end{array}$ & $\begin{array}{l}\text { Positive- } \\
\text { test } \\
\text { likelihood } \\
(95 \% \mathrm{CI})\end{array}$ & $\begin{array}{l}\text { Negative- } \\
\text { test } \\
\text { likelihood } \\
(95 \% \mathrm{CI})\end{array}$ & $\begin{array}{l}\text { Odds } \\
\text { Ratio } \\
(95 \% \text { CI) }\end{array}$ & $P$ value \\
\hline $\begin{array}{l}\text { Elevated } \\
\text { lactate }(\mathrm{n}= \\
381)\end{array}$ & $\begin{array}{l}0.63(0.56- \\
0.7)\end{array}$ & $\begin{array}{l}0.63(0.59- \\
0.66)\end{array}$ & $\begin{array}{l}0.63(0.60- \\
0.66)\end{array}$ & $\begin{array}{l}1.71(1.47- \\
1.96)\end{array}$ & $\begin{array}{l}0.58(0.48- \\
0.7)\end{array}$ & $\begin{array}{l}2.93(2.09- \\
4.14)\end{array}$ & $<0.0001$ \\
\hline $\begin{array}{l}\text { Elevated } \\
\text { PCT }(\mathrm{n}= \\
527)\end{array}$ & $\begin{array}{l}0.81(0.74- \\
0.86)\end{array}$ & $\begin{array}{l}0.47(0.43- \\
0.50)\end{array}$ & $\begin{array}{l}0.54(0.51- \\
0.57)\end{array}$ & $\begin{array}{l}1.51(1.36- \\
1.66)\end{array}$ & $\begin{array}{l}0.41(0.31- \\
0.55)\end{array}$ & $\begin{array}{l}3.64(2.46- \\
5.51)\end{array}$ & $<0.0001$ \\
\hline $\begin{array}{l}\text { Elevated hs- } \\
\text { CRP ( }= \\
785)\end{array}$ & $\begin{array}{l}0.88(0.82- \\
0.92)\end{array}$ & $\begin{array}{l}0.11(0.09- \\
0.14)\end{array}$ & $\begin{array}{l}0.28(0.25- \\
0.31)\end{array}$ & $\begin{array}{l}0.99(0.92- \\
1.04)\end{array}$ & $\begin{array}{l}1.09(0.71- \\
1.66)\end{array}$ & $\begin{array}{l}0.91(0.55- \\
1.55)\end{array}$ & 0.79 \\
\hline $\begin{array}{l}\text { Elevated } \\
\text { lactate and } \\
\text { PCT }(\mathrm{n}= \\
255)\end{array}$ & $\begin{array}{l}0.53(0.46- \\
0.6)\end{array}$ & $\begin{array}{l}0.78(0.75- \\
0.81)\end{array}$ & $\begin{array}{l}0.72(0.69- \\
0.75)\end{array}$ & $\begin{array}{l}2.41(1.98- \\
2.91)\end{array}$ & $\begin{array}{l}0.60(0.51- \\
0.70)\end{array}$ & $\begin{array}{l}3.98(2.81- \\
5.63)\end{array}$ & $<0.0001$ \\
\hline $\begin{array}{l}\text { Elevated } \\
\text { lactate } \\
\text { and/or PCT } \\
(\mathrm{n}=653)\end{array}$ & $\begin{array}{l}0.91(0.87- \\
0.95)\end{array}$ & $\begin{array}{l}0.31(0.28- \\
0.35)\end{array}$ & $\begin{array}{l}0.45(0.41- \\
0.48)\end{array}$ & $\begin{array}{l}1.33(1.24- \\
1.42)\end{array}$ & $\begin{array}{l}0.28(0.17- \\
0.43)\end{array}$ & $\begin{array}{l}4.83(2.84- \\
8.69)\end{array}$ & $<0.0001$ \\
\hline $\begin{array}{l}\text { Elevated hs- } \\
\text { CRP and } \\
\text { PCT (n = } \\
497)\end{array}$ & $\begin{array}{l}0.76(0.69- \\
0.81)\end{array}$ & $\begin{array}{l}0.49(0.46- \\
0.53)\end{array}$ & $\begin{array}{l}0.55(0.52- \\
0.59)\end{array}$ & $\begin{array}{l}1.5(1.34- \\
1.66)\end{array}$ & $\begin{array}{l}0.49(0.38- \\
0.63)\end{array}$ & $\begin{array}{l}3.04(2.1- \\
4.44)\end{array}$ & $<0.0001$ \\
\hline $\begin{array}{l}\text { Elevated hs- } \\
\text { CRP and/or } \\
\text { PCT (n = } \\
815)\end{array}$ & $\begin{array}{l}0.93(0.88- \\
0.96)\end{array}$ & $\begin{array}{l}0.08(0.06- \\
0.11)\end{array}$ & $\begin{array}{l}0.27(0.24- \\
0.3)\end{array}$ & $\begin{array}{l}1.01(0.96- \\
1.05)\end{array}$ & $\begin{array}{l}0.86(0.49- \\
1.49)\end{array}$ & $\begin{array}{l}1.18(0.63- \\
2.34)\end{array}$ & 0.70 \\
\hline $\begin{array}{l}\text { Elevated } \\
\text { lactate and }\end{array}$ & $\begin{array}{l}0.55(0.48- \\
0.62)\end{array}$ & $\begin{array}{l}0.68(0.64- \\
0.71)\end{array}$ & $\begin{array}{l}0.65(0.62- \\
0.68)\end{array}$ & $\begin{array}{l}1.71(1.44- \\
2.01)\end{array}$ & $\begin{array}{l}0.67(0.56- \\
0.78)\end{array}$ & $\begin{array}{l}2.57(1.84- \\
3.6)\end{array}$ & $<0.0001$ \\
\hline
\end{tabular}




\begin{tabular}{l|l|l|l|l|l|l|l}
\hline $\begin{array}{l}\text { hs-CRP }(\mathrm{n}= \\
329)\end{array}$ & & & & & & & \\
\hline $\begin{array}{l}\text { Elevated } \\
\text { lactate } \\
\text { and/or hs- }\end{array}$ & $0.96(0.93-$ & $\begin{array}{l}0.06(0.04- \\
0.08)\end{array}$ & $\begin{array}{l}0.26(0.23- \\
0.29)\end{array}$ & $\begin{array}{l}1.03(0.99- \\
1.06)\end{array}$ & $\begin{array}{l}0.58(0.27- \\
1.24)\end{array}$ & $\begin{array}{l}1.76(0.77- \\
4.72)\end{array}$ & 0.23 \\
CRP (n= \\
$837)$
\end{tabular}

$4 \mathrm{~N}=886 ; \mathrm{n}$ : number of samples within the pattern. Interpretation of results: negative-test likelihood $<0.6$ will 5 indicate clinical usefulness.

6

7 


\section{Table 3 (on next page)}

Table 3. Diagnostic variables associated with elevation of either PCT, LAC, or hs-CRP, two variables, and all variables for predicting blood culture positive for GNB.

Diagnostic variables associated with elevation of either procalcitonin (PCT $\geq 0.5 \mathrm{ng} / \mathrm{ml}$ ), blood lactate (LAC $\geq 19.8 \mathrm{mg} / \mathrm{dl}$ ), or high-sensitivity C-reactive protein (hs-CRP $\geq 0.8 \mathrm{mg} / \mathrm{dl}$ ), two variables, and all variables for predicting blood culture positive for gram-negative bacteria. 
1 Table 3. Diagnostic variables associated with elevation of either procalcitonin (PCT $\geq 0.5 \mathrm{ng} / \mathrm{ml}$ ),

2 blood lactate (LAC $\geq 19.8 \mathrm{mg} / \mathrm{dl}$ ), or high-sensitivity C-reactive protein (hs-CRP $\geq 0.8 \mathrm{mg} / \mathrm{dl}$ ), two

3 variables, and all variables for predicting blood culture positive for gram-negative bacteria.

\begin{tabular}{|c|c|c|c|c|c|c|c|}
\hline Pattern (n) & $\begin{array}{l}\text { Sensitivity } \\
(95 \% \\
\text { Confidence } \\
\text { Interval, } \\
\text { CI) }\end{array}$ & $\begin{array}{l}\text { Specificity } \\
(95 \% \text { CI) }\end{array}$ & $\begin{array}{l}\text { Overall } \\
\text { Accuracy (= } \\
\text { Diagnostic } \\
\text { Effectiveness) } \\
(95 \% \text { CI) }\end{array}$ & $\begin{array}{l}\text { Positive-test } \\
\text { likelihood } \\
(95 \% \mathrm{CI})\end{array}$ & $\begin{array}{l}\text { Negative- } \\
\text { test } \\
\text { likelihood } \\
(95 \% \mathrm{CI})\end{array}$ & $\begin{array}{l}\text { Odds Ratio } \\
(95 \% \mathrm{CI})\end{array}$ & $P$ value \\
\hline $\begin{array}{l}\text { Elevated lactate }(n= \\
337)\end{array}$ & $\begin{array}{l}0.64(0.55- \\
0.73)\end{array}$ & $\begin{array}{l}0.63(0.59- \\
0.66)\end{array}$ & $\begin{array}{l}0.63(0.6- \\
0.66)\end{array}$ & $\begin{array}{l}1.73(1.46- \\
2.02)\end{array}$ & $\begin{array}{l}0.57(0.44- \\
0.71)\end{array}$ & $\begin{array}{l}3.04(2.02- \\
4.63)\end{array}$ & $<0.0001$ \\
\hline $\begin{array}{l}\text { Elevated PCT }(n= \\
479)\end{array}$ & $\begin{array}{l}0.88(0.81- \\
0.93)\end{array}$ & $\begin{array}{l}0.47(0.43- \\
0.50)\end{array}$ & $\begin{array}{l}0.53(0.5- \\
0.56)\end{array}$ & $\begin{array}{l}1.65(1.49- \\
1.81)\end{array}$ & $\begin{array}{l}0.26(0.16- \\
0.40)\end{array}$ & $\begin{array}{l}6.44(3.65- \\
12.15)\end{array}$ & $<0.0001$ \\
\hline $\begin{array}{l}\text { Elevated hs-CRP (n } \\
=726)\end{array}$ & $\begin{array}{l}0.90(0.84- \\
0.95)\end{array}$ & $\begin{array}{l}0.11(0.09- \\
0.14)\end{array}$ & $\begin{array}{l}0.23(0.21- \\
0.26)\end{array}$ & $\begin{array}{l}1.02(0.94- \\
1.07)\end{array}$ & $\begin{array}{l}0.85(0.48- \\
1.49)\end{array}$ & $\begin{array}{l}1.20(0.62- \\
2.49)\end{array}$ & 0.70 \\
\hline $\begin{array}{l}\text { Elevated lactate and } \\
\text { PCT }(n=224)\end{array}$ & $\begin{array}{l}0.58(0.49- \\
0.67)\end{array}$ & $\begin{array}{l}0.78(0.75- \\
0.81)\end{array}$ & $\begin{array}{l}0.75(0.72- \\
0.78)\end{array}$ & $\begin{array}{l}2.64(2.14- \\
3.22)\end{array}$ & $\begin{array}{l}0.54(0.43- \\
0.65)\end{array}$ & $\begin{array}{l}4.9(3.24- \\
7.45)\end{array}$ & $<0.0001$ \\
\hline $\begin{array}{l}\text { Elevated lactate } \\
\text { and/or PCT }(\mathrm{n}= \\
592)\end{array}$ & $\begin{array}{l}0.94(0.89- \\
0.98)\end{array}$ & $\begin{array}{l}0.31(0.28- \\
0.35)\end{array}$ & $\begin{array}{l}0.41(0.38- \\
0.44)\end{array}$ & $\begin{array}{l}1.38(1.28- \\
1.47)\end{array}$ & $\begin{array}{l}0.18(0.09- \\
0.35)\end{array}$ & $\begin{array}{l}7.75(3.56- \\
20.03)\end{array}$ & $<0.0001$ \\
\hline $\begin{array}{l}\text { Elevated hs-CRP } \\
\text { and PCT }(n=453)\end{array}$ & $\begin{array}{l}0.83(0.76- \\
0.89)\end{array}$ & $\begin{array}{l}0.49(0.46- \\
0.53)\end{array}$ & $\begin{array}{l}0.55(0.51- \\
0.58)\end{array}$ & $\begin{array}{l}1.65(1.47- \\
1.83)\end{array}$ & $\begin{array}{l}0.34(0.22- \\
0.49)\end{array}$ & $\begin{array}{l}4.89(2.96- \\
8.43)\end{array}$ & $<0.0001$ \\
\hline $\begin{array}{l}\text { Elevated hs-CRP } \\
\text { and/or PCT }(\mathrm{n}= \\
752)\end{array}$ & $\begin{array}{l}0.95(0.90- \\
0.98)\end{array}$ & $\begin{array}{l}0.08(0.06- \\
0.11)\end{array}$ & $\begin{array}{l}0.22(0.19- \\
0.25)\end{array}$ & $\begin{array}{l}1.04(0.98- \\
1.08)\end{array}$ & $\begin{array}{l}0.58(0.26- \\
1.26)\end{array}$ & $\begin{array}{l}1.8(0.76- \\
5.23)\end{array}$ & 0.24 \\
\hline $\begin{array}{l}\text { Elevated lactate and } \\
\text { hs-CRP }(\mathrm{n}=294)\end{array}$ & $\begin{array}{l}0.58(0.49- \\
0.67)\end{array}$ & $\begin{array}{l}0.68(0.64- \\
0.71)\end{array}$ & $\begin{array}{l}0.66(0.63- \\
0.7)\end{array}$ & $\begin{array}{l}1.81(1.49- \\
2.15)\end{array}$ & $\begin{array}{l}0.62(0.49- \\
0.75)\end{array}$ & $\begin{array}{l}2.91(1.94- \\
4.39)\end{array}$ & $<0.0001$ \\
\hline $\begin{array}{l}\text { Elevated lactate } \\
\text { and/or hs-CRP ( } \mathrm{n}= \\
769)\end{array}$ & $\begin{array}{l}0.97(0.92- \\
0.99)\end{array}$ & $\begin{array}{l}0.06(0.04- \\
0.08)\end{array}$ & $\begin{array}{l}0.2(0.17- \\
0.23)\end{array}$ & $\begin{array}{l}1.03(0.98- \\
1.06)\end{array}$ & $\begin{array}{l}0.52(0.2- \\
1.35)\end{array}$ & $\begin{array}{l}1.99(0.70- \\
7.74)\end{array}$ & 0.27 \\
\hline $\begin{array}{l}\text { Elevated lactate and } \\
\text { PCT and hs-CRP (n } \\
=206 \text { ) }\end{array}$ & $\begin{array}{l}0.53(0.44- \\
0.62)\end{array}$ & $\begin{array}{l}0.80(0.77- \\
0.83)\end{array}$ & $\begin{array}{l}0.76(0.73- \\
0.79)\end{array}$ & $\begin{array}{l}2.64(2.1- \\
3.27)\end{array}$ & $\begin{array}{l}0.59(0.48- \\
0.7)\end{array}$ & $\begin{array}{l}4.48(2.96- \\
6.81)\end{array}$ & $<0.0001$ \\
\hline
\end{tabular}

$4 \quad \mathrm{~N}=886 ; \mathrm{n}$ : number of samples within the pattern. 


\section{Table 4 (on next page)}

Table 4. Diagnostic variables associated with elevation of either PCT, LAC, or hs-CRP, two variables, and all variables for predicting blood culture positive for GPB.

Diagnostic variables associated with elevation of either procalcitonin (PCT $\geq 0.5 \mathrm{ng} / \mathrm{ml}$ ), blood lactate (LAC $\geq 19.8 \mathrm{mg} / \mathrm{dl}$ ), or high-sensitivity C-reactive protein (hs-CRP $\geq 0.8 \mathrm{mg} / \mathrm{dl}$ ), two variables, and all variables for predicting blood culture positive for gram-positive bacteria. 
1 Table 4. Diagnostic variables associated with elevation of either procalcitonin (PCT $\geq 0.5 \mathrm{ng} / \mathrm{ml}$ ),

2 blood lactate (LAC $\geq 19.8 \mathrm{mg} / \mathrm{dl}$ ), or high-sensitivity C-reactive protein (hs-CRP $\geq 0.8 \mathrm{mg} / \mathrm{dl}$ ), two

3 variables, and all variables for predicting blood culture positive for gram-positive bacteria.

\begin{tabular}{|c|c|c|c|c|c|c|c|}
\hline Pattern (n) & $\begin{array}{l}\text { Sensitivity } \\
(95 \% \\
\text { Confidence } \\
\text { Interval, } \\
\text { CI) }\end{array}$ & $\begin{array}{l}\text { Specificity } \\
(95 \% \text { CI) }\end{array}$ & $\begin{array}{l}\text { Overall } \\
\text { Accuracy (= } \\
\text { Diagnostic } \\
\text { Effectiveness) } \\
(95 \% \text { CI) }\end{array}$ & $\begin{array}{l}\text { Positive-test } \\
\text { likelihood } \\
\text { (95\% CI) }\end{array}$ & $\begin{array}{l}\text { Negative-test } \\
\text { likelihood } \\
(95 \% \mathrm{CI})\end{array}$ & $\begin{array}{l}\text { Odds } \\
\text { Ratio } \\
(95 \% \text { CI) }\end{array}$ & $P$ value \\
\hline $\begin{array}{l}\text { Elevated lactate } \\
(\mathrm{n}=302)\end{array}$ & $\begin{array}{l}0.63(0.51- \\
0.74)\end{array}$ & $\begin{array}{l}0.63(0.6- \\
0.66)\end{array}$ & $\begin{array}{l}0.63(0.6- \\
0.66)\end{array}$ & $\begin{array}{l}1.7(1.36- \\
2.04)\end{array}$ & $\begin{array}{l}0.59(0.42- \\
0.78)\end{array}$ & $\begin{array}{l}2.88(1.7- \\
4.94)\end{array}$ & $<0.0001$ \\
\hline $\begin{array}{l}\text { Elevated PCT (n } \\
=418)\end{array}$ & $\begin{array}{l}0.68(0.57- \\
0.79)\end{array}$ & $\begin{array}{l}0.47(0.43- \\
0.50)\end{array}$ & $\begin{array}{l}0.49(0.45- \\
0.52)\end{array}$ & $\begin{array}{l}1.28(1.06- \\
1.49)\end{array}$ & $\begin{array}{l}0.68(0.47- \\
0.93)\end{array}$ & $\begin{array}{l}1.89(1.11- \\
3.33)\end{array}$ & 0.02 \\
\hline $\begin{array}{l}\text { Elevated hs- } \\
\text { CRP }(n=673)\end{array}$ & $\begin{array}{l}0.84(0.73- \\
0.91)\end{array}$ & $\begin{array}{l}0.11(0.09- \\
0.14)\end{array}$ & $\begin{array}{l}0.18(0.15- \\
0.21)\end{array}$ & $\begin{array}{l}0.94(0.82- \\
1.02)\end{array}$ & $\begin{array}{l}1.47(0.83- \\
2.49)\end{array}$ & $\begin{array}{l}0.64(0.32- \\
1.37)\end{array}$ & 0.25 \\
\hline $\begin{array}{l}\text { Elevated lactate } \\
\text { and PCT }(\mathrm{n}= \\
184)\end{array}$ & $\begin{array}{l}0.45(0.34- \\
0.57)\end{array}$ & $\begin{array}{l}0.78(0.75- \\
0.81)\end{array}$ & $\begin{array}{l}0.75(0.72- \\
0.78)\end{array}$ & $\begin{array}{l}2.06(1.52- \\
2.7)\end{array}$ & $\begin{array}{l}0.70(0.55- \\
0.85)\end{array}$ & $\begin{array}{l}2.93(1.73- \\
4.96)\end{array}$ & $<0.0001$ \\
\hline $\begin{array}{l}\text { Elevated lactate } \\
\text { and/or PCT }(\mathrm{n}= \\
536)\end{array}$ & $\begin{array}{l}0.86(0.76- \\
0.93)\end{array}$ & $\begin{array}{l}0.31(0.28- \\
0.35)\end{array}$ & $\begin{array}{l}0.37(0.33- \\
0.4)\end{array}$ & $\begin{array}{l}1.26(1.11- \\
1.37)\end{array}$ & $\begin{array}{l}0.44(0.24- \\
0.76)\end{array}$ & $\begin{array}{l}2.87(1.43- \\
6.41)\end{array}$ & 0.003 \\
\hline $\begin{array}{l}\text { Elevated hs- } \\
\text { CRP and PCT (n } \\
=394)\end{array}$ & $\begin{array}{l}0.63(0.51- \\
0.74)\end{array}$ & $\begin{array}{l}0.49(0.46- \\
0.53)\end{array}$ & $\begin{array}{l}0.51(0.47- \\
0.54)\end{array}$ & $\begin{array}{l}1.25(1.01- \\
1.48)\end{array}$ & $\begin{array}{l}0.75(0.54- \\
0.99)\end{array}$ & $\begin{array}{l}1.67(0.99- \\
2.86)\end{array}$ & 0.06 \\
\hline $\begin{array}{l}\text { Elevated hs- } \\
\text { CRP and/or } \\
\text { PCT }(n=697)\end{array}$ & $\begin{array}{l}0.89(0.80- \\
0.95)\end{array}$ & $\begin{array}{l}0.08(0.06- \\
0.11)\end{array}$ & $\begin{array}{l}0.16(0.13- \\
0.19)\end{array}$ & $\begin{array}{l}0.97(0.87- \\
1.03)\end{array}$ & $\begin{array}{l}1.32(0.66- \\
2.56)\end{array}$ & $\begin{array}{l}0.73(0.33- \\
1.86)\end{array}$ & 0.57 \\
\hline $\begin{array}{l}\text { Elevated lactate } \\
\text { and hs-CRP }(n= \\
\text { 258) }\end{array}$ & $\begin{array}{l}0.51(0.39- \\
0.63)\end{array}$ & $\begin{array}{l}0.68(0.64- \\
0.71)\end{array}$ & $\begin{array}{l}0.66(0.63- \\
0.7)\end{array}$ & $\begin{array}{l}1.58(1.21- \\
1.99)\end{array}$ & $0.73(0.56-0.9)$ & $\begin{array}{l}2.17(1.3- \\
3.65)\end{array}$ & 0.002 \\
\hline $\begin{array}{l}\text { Elevated lactate } \\
\text { and/or hs-CRP } \\
(\mathrm{n}=717)\end{array}$ & $\begin{array}{l}0.96(0.88- \\
0.99)\end{array}$ & $\begin{array}{l}0.06(0.04- \\
0.08)\end{array}$ & $\begin{array}{l}0.15(0.12- \\
0.17)\end{array}$ & $\begin{array}{l}1.02(0.94- \\
1.06)\end{array}$ & $\begin{array}{l}0.67(0.22- \\
1.95)\end{array}$ & $\begin{array}{l}1.51(0.46- \\
7.83)\end{array}$ & 0.67 \\
\hline $\begin{array}{l}\text { Elevated lactate } \\
\text { and PCT and } \\
\text { hs-CRP (n = }\end{array}$ & $\begin{array}{l}0.41(0.3- \\
0.53)\end{array}$ & $\begin{array}{l}0.80(0.77- \\
0.83)\end{array}$ & $\begin{array}{l}0.76(0.73- \\
0.79)\end{array}$ & $\begin{array}{l}2.04(1.46- \\
2.72)\end{array}$ & $\begin{array}{l}0.74(0.59- \\
0.87)\end{array}$ & $\begin{array}{l}2.76(1.61- \\
4.68)\end{array}$ & $<0.0001$ \\
\hline
\end{tabular}




\begin{tabular}{l|l} 
& \\
\hline
\end{tabular}

$4 \quad \mathrm{~N}=886 ; \mathrm{n}$ : number of samples within the pattern

5

6 